\title{
State of knowledge of the tachinid fauna of Eastern Asia, with new data from North Korea. Part I. Phasiinae
}

\author{
Agnieszka DraBER-MoŃKO
}

Museum and Institute of Zoology,PAS, Wilcza 64,00-679 Warszawa; e-mail: draber@mitz.waw.pl

\begin{abstract}
The present state of knowledge of the tachinid fauna of Eastern Asia is reviewed. The material from the subfamily Phasiinae collected in North Korea by five expeditions of researchers from the Institute of Zoology PAS, Warsaw, Poland was studied. Thirteen species of the phasiine flies are recorded. Ten species are reported for the first time in the fauna of North Korea. Two new species are described and illustrated: Dionaea karinae sp. nov., and Hemyda dominikae sp. nov.
\end{abstract}

Key words: Diptera, Tachinidae, Phasiinae, new species, North Korea

\section{INTRODUCTION}

The cosmopolitan family Tachinidae is one of the largest families of Diptera. More than 8,500 species are distributed in all zoogeographic regions, and more than 1,600 species are recorded from the Palaearctic region (Richter 2004). The greatest number of the tachinid species occurs in the Palaearctic, Nearctic, Neotropical and Afrotropical regions. About a thousand species are recorded from the Oriental region (Crosskey 1977). The smallest number of tachinid species occurs in the Australasian and Oceanian regions (Cantrell \& Crosskey 1989).

The Tachinidae are divided into four subfamilies: Phasiinae, Dexiinae, Exoristinae and Tachininae. The Phasiinae are a small subfamily with about five hundred species known worldwide. About 170 species of the Phasiinae are recorded from the Palaearctic region (Herting \& Dely-Draskovits 1993, Ziegler \& Shima 1996) and 68 species from the Russian Far East (Ziegler \& Shima 1996, Richter 2004). All Tachinidae are, in the larval stage, endoparasitic in other arthropods, almost exclusively in insects. The majority of phasiin species of which the biology and the preimaginal stages have been studied are endoparasitoids specialized on Heteroptera (Pentatomidae, Cydnidae, Coreidae, Lygaeidae and Nabidae).

\section{REVIEW OF THE TACHINID FAUNA OF EASTERN ASIA}

The tachinid fauna of various parts of the eastern Asian continent has not been studied equally well. Far more data are available on tachinid flies of West Siberia to Mongolia, Lake Baikal, Transbaikalia and the Russian Far East (Kamchatka Peninsula, Kuril Islands, Sakhalin and Ussuria) (Becker \& Schnabl 1926). Numerous research expeditions organised mainly by zoologists from Moscow and from St. Petersburg, have made it possible for dipterologists to collect and analyse new materials and write a number of papers about tachinid genera of the Palaearctic distribution, including many works by Jacobson (1899), Rohdendorf (1923, 1924 a, b, 1927, 1928, 1933 a, b, 1934, 1947, 1949), Zimin $(1926,1928,1929$ a, b, 1931 a, b, 1935, $1947,1949,1951,1954,1957,1958,1960,1961,1963,1965,1966,1967,1970,1974,1980)$, 
Zimin \& Kolomyetz (1983, 1984), Kolomyetz (1952, 1966, 1967, 1970, 1971, 1973 a, b, 1974 a, b, 1975, 1976, 1977 a, b, 1979, 1987 a, b, 1989, 1990, 1992), Kolomyetz \& Bogdanova (1980), Rubtzov (1947), Kamenkova (1956), Viktorov (1960, 1966), Viktorov \& Kozharina (1961), Shabliovskij \& Lugoviztyna (1971 a, b), Borisova-Zinoveva (1962, 1966 a, b), Hitzova (1975), Hitzova \& Vinokurov (1977) and Richter (1976 a, b, 1977, 1980, 2002, 2003, 2004). Faunistical, taxonomical and biological papers on the Tachinidae of Eastern Russia have been published, including works of Wiedemann (1830), van der Wulp $(1881,1893)$, Loew (1844, $1845,1847,1858)$, Macquart (1843, 1845, 1847, 1851), Walker (1850-1856, 1859-1860, 1860), Mesnil (1944-1975), Draber-Mońko (1965), Herting (1983 a, b), Shima (1992), Ziegler (1994), Richter \& Wood (1995, 2003), Ziegler \& Shima (1996), Richter \& Markova (1999), Markova (1999). Markova (2000 a, b), Markova \& Lutchenko (2001), and Markova et al. (2002). A special position in the research on the Russian Tachinidae (and the Phasiinae too) is occupied by the Russian dipterologist V.A. Richter who devoted many years of her life to the study of the Tachinidae of Siberia, Mongolia and the Russian Far East. Her many papers deal with tachinid flies from South, North and East Siberia, from Russian Far East to the Kuril Islands, as well as from entire Siberia (Richter 1976 a, b, 1977, 1979, 1980, 1981, 1982, 2002, 2003 , 2004). Her research work was crowned with a vast monograph - "Fam. Tachinidae tachinids in: Key to the insects of Russian Far East" - published in 2004.

The tachinid fauna of Japan has probably been described most extensively, e.g. in papers by Matsumura (1904, 1911, 1916, 1931), Loew (1858), Baranov (1934 a, b, c, 1935, 1952), Takano (1956, 1958), Ueda (1960 a, b), Kocha (1969, 1971), Mesnil (1963, 1968, 1970, 1971), Mesnil \& Pschorn-Walcher (1968), Mesnil \& Shima (1977, 1978, 1979), Shima (1980, 1992, 1999).

The tachinid fauna of China has been investigated by such dipterologists as Walker (18501856, 1859-1860, 1860), Loew (1858), Aldrich (1928), Malloch (1934), Villeneuve (1936 a, b; 1937), Sun \& Marshall (1995, 2003), Sun (1996). A prominent place in the research on Tachinidae is occupied by the Chinese dipterologist Chao C. M. who devoted his life to the study of the Tachinidae of China. His many papers are devoted to tachinid flies from entire China (1962 a, b, 1963, 1964 a, b, 1965, 1974, 1976, 1979) and Chao \& Liang (1980), Chao \& Shi (1981). His research work was crowned with a vast monograph:"The Tachinidae flies of China", published in 1998 and another monograph written in cooperation with others "Diptera, Tachinidae, Fauna Sinica, Insecta", published in 2001.

A later catalogue of the Tachinidae of the Palaearctic region was published by Herting \& Dely-Draskovits (1993).

The Oriental fauna has been investigated by such dipterologist as Villers (1789), Walker (1849, 1850-1856, 1858, 1860), Coquillett (1910), Matsumura (1911), de Meijere (1917), Bezzi (1925), Curran (1927, 1934, 1938), Aldrich (1928), Malloch (1930, 1934), Baranov (1932 a, b, c, 1934 a, b, c, 1936, 1938), Mesnil (1942, 1953 a, b, 1957, 1968), Séguy (1948 a, b, 1950), Reinhard (1956), Crosskey (1966 a, b, 1967 a, b, 1969, 1976, 1980), Mesnil \& Shima (1979). A later catalogue of the Tachinidae of the Oriental region was published by Cantrell \& Crosskey (1977).

The tachinid fauna of Korea is very poorly known. Recent papers on the Tachinidae (excluding Phasiinae) of South Korea have been published by Han \& Kim (1983). A new species of Phasiinae has recently been described from North Korea (Kolomyetz 1976, 1977 a, b). There have been no faunistical papers on this subfamily of dipterans in North Korea, and the fragmentary data scattered in different papers do not provide an adequate picture of this interesting fauna.

While the Korean Peninsula is traditionally considered part of the Palaearctic realm, the phasiin fauna of this region contains a number of Siberian-Manchurian elements and typically 
Oriental forms. A zoogeographical analysis will be carried out when the entire study material has been processed.

The systematic arrangement of the present paper follows that provided by Tschorsnig \& Richter (1998) and Richter (2004).

\section{MATERIAL AND METHODS}

The material collected in North Korea by researchers from the Institute of Zoology PAS is fairly small. However, because of poor knowledge of this group of Diptera in Eastern Asia, including Korea, the material was studied. Phasiin flies were collected during five expeditions to North Korea: in 1959, 1965, 1966, 1970 and in 1990. Detailed descriptions of these expeditions are in Mroczkowski (1972) and in Bańkowska \& Sterzyńska (1997).

The scanty material of Phasiinae includes 52 specimens collected with a sweeping net or using Moericke's yellow traps placed on grass and in brushwood. The locations of the sampling areas in North Korea are presented in Fig. 1.

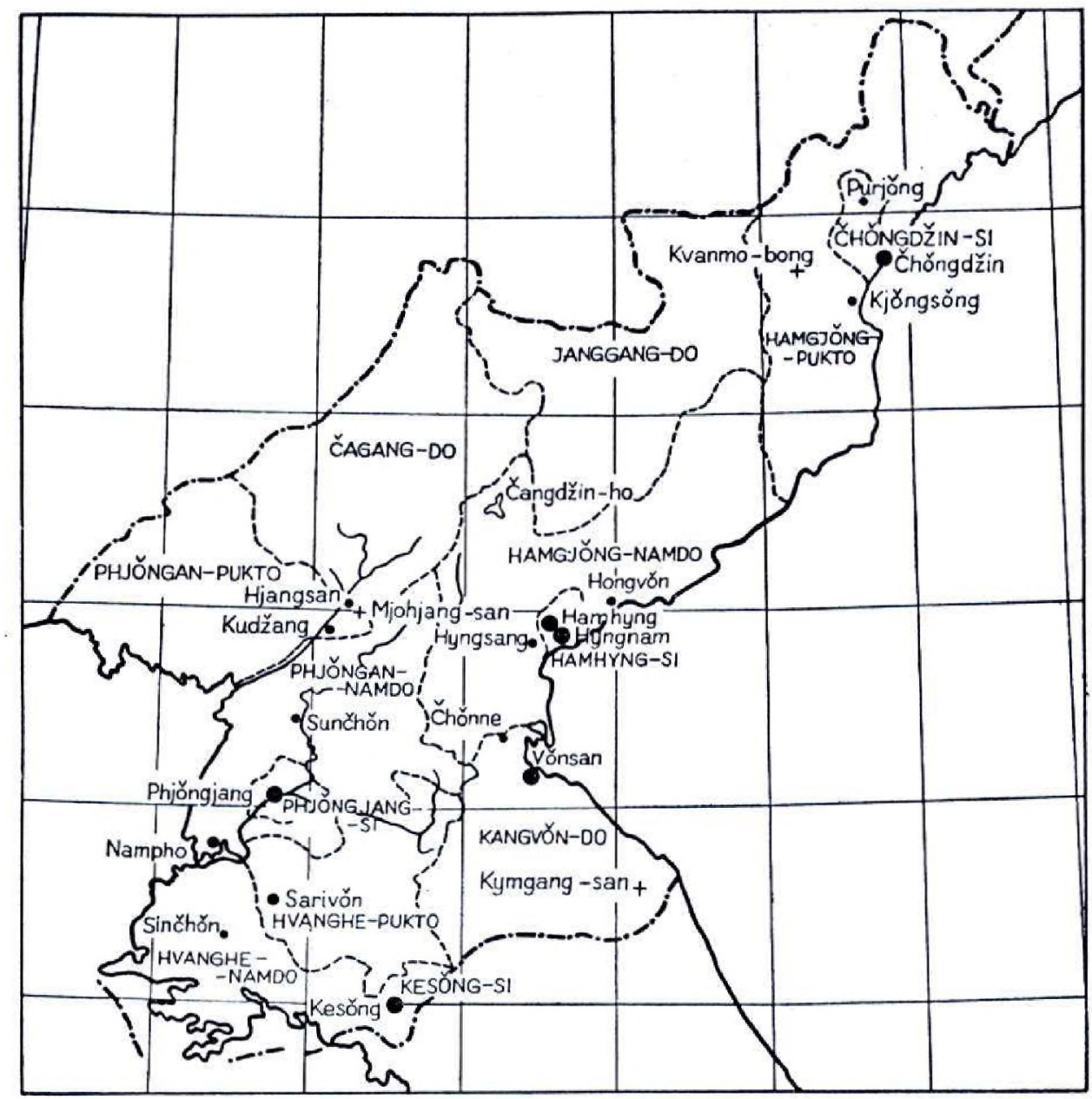

Fig.1. Location of sampling areas in North Korea in the years 1959-1990. 


\section{SYSTEMATIC REVIEW OF SPECIES}

\section{Subfamily Phasiinae}

Tribe Hermyini

Hermya Robineau-Desvoidy, 1830

\section{Hermya beelzebul (Wiedemann, 1830)}

Tachina beelzebul Wiedemann, 1830: 301. Type locality: Java.

Material examined: North Korea, Chongdžin-si prov., in Kjŏngsŏng distr., Onpho-ri ad Chongdžin-si, 18.08.1959, 1 female, leg. B. Pisarski and J. Prószyński; Phjŏngjang-si prov., in the Jongsŏng distr., town Maram ad Phjŏngjang-si in the Jongak-san Mts., 30.07.1959, 1 male, leg. B. Pisarski and J. Prószyński; in the Hamhyng-si prov., in the Hamdžu distr., in the vicinity of the village Hŭngpong-ri, 12.06.1965, 1 female, leg. M. Mroczkowski and A. Riedel; in the Phjŏngan-pukto prov., Mjohjang-san Mts., near Mjohjang-san hotel, 9-12. 06.1990, 1 female, leg. E. Chudzicka, E. Kierych and R. Pisarska.

Distribution: Palaearctic: Asia, Japan (Honshu, Shikoku and Kyushu), Oriental Region (Borneo, Burma, Ceylon, China, Hong Kong, India [Assam, Uttar Pradesh, Madras], Java, Malaya, Nepal, Philippines [Mindanao], Sumatra, Thailand, Vietnam) [Crosskey (1977), Herting \& Dely-Draskovits (1993) and Richter (2004)].

Tribe Phasiini

Ectophasia Townsend, 1912

\section{Ectophasia crassipennis (Fabricius, 1794)}

Syrphus crassipennis Fabricius, 1794: 284. Type locality: Paris (France).

Material examined: North Korea, Kangvŏn-do prov., Kymgang-san Mts., Onjong-ri near Kymgang-san hotel, on the river, 22.06.1990, 1 male, leg. E. Chudzicka, E. Kierych and R. Pisarska.

Distribution: Europe (Mediterranean region, northwards to Germany, Poland, Russian central European territory, Ukraine; Transcaucasia, S. Siberia, Russian Far East (Amuria, Ussuria), Japan (Kyushu to Hokkaido) [Herting \& Dely-Draskovits (1993), Ziegler \& Shima (1996), Richter (2004)].

\section{Ectophasia rotundiventris (Loew, 1858)}

Phasia rotundiventris Loew, 1858: 109. Type locality: Japan.

Material examined: North Korea, Chŏngdžin-si prov., Kjŏngsŏng distr., Onpho-ri ad Chŏngdžin, 16.08.1959, 6 males, 3 females; 18.08.1959, 6 males, 1 female; 19.08.1959, 2 males, 4 females, leg. B. Pisarski and J. Prószyński; Kwanmo-bong Mts., Chŏngdžin-si prov., Džuyr ad Chŏngdžin, 24.08.1959, 1 male, leg. B. Pisarski and J. Prószyński; Hamgjŏng-punkto prov., Kjŏngsŏng distr., Onpho-ri, 8.09.1966, 1 male, leg. C. Dziadosz and H. Szelęgiewicz; 5.09.1970, 2 males; 6.09.1970, 1 male, 7.09.1970 1 male, leg. R. Bielawski and M. Mroczkowski; in the Phjŏngan-pukto prov. Mjohjang-san Mts., near Mjohjang-san hotel, ravine, 11.06.1990, 1 female, leg. E. Chudzicka, E. Kierych and R. Pisarska.

Distribution: East Siberia (Chita, Yakutia), S. Kuril Islands (Kunashir), Russian Far East (Amuria, Ussuria), Japan (Hokkaido, Honshu, Shikoku and Kyushu) and N. China (Herting \& Dely-Draskovits (1993), Ziegler \& Shima (1996), Richter (2004)]. 
Gymnosoma Meigen, 1803

\section{Gymnosoma dolycoridis Dupuis, 1961}

Gymnosoma dolycoridis Dupuis, 1961: 72. Type locality: Richelieu, Indre-et-Loire (France)

Material examined: North Korea, Chŏngdžin-si prov., Kjŏngsŏng distr., Onpho-ri ad Chŏngdžin, 14-16.08.1959, 1 male; 16.08.1959, 2 males; 19.08.1959, 3 males, 2 females; 22.08.1959, 1 female, leg. B. Pisarski and J. Prószyński; in the Phjŏngan-pukto prov. Hjangsan distr., Mjohjang-san Mts., Hjangam-ri, 16-22.06.1965, 1 male, leg. M. Mroczkowski and A. Riedel.

Distribution: Europe: Mediterranean region, northwards to Czech Republic, Slovakia, Poland, N. Germany, Ukraine and North European territory of Russia, and Asia: N. Caucasus, Transcaucasia, Russian Middle Asia, S. Siberia (Chita, Tuva, Tomsk Province), Russian Far East (Ussuria) and N. China (Herting \& Dely-Draskovits (1993), Ziegler \& Shima (1996), Richter (2004)].

\section{Gymnosoma inornata Zimin, 1966}

Gymnosoma inornata Zimin, 1966: 446. Type locality: Potu nr Geokchev (Azerbaijan)

Material examined: North Korea, Kangvŏn-do prov., Kumgang-san Mts., Onjong-ri near Kumgang-san hotel 23-25. VI.1990, 1 male, leg. E. Chudzicka, E. Kierych and R. Pisarska.,

Distribution: S. Europe (Spain, Switzerland, Greece, Ukraine); Asia: S. Siberia, (Altai, Tomsk Province, Irkutsk, Chita, Altaj), Russian Far East (Amuria, Ussuria, Sakhalin Island, Japan, (Kyushu, Honshu, Hokkaido), N. China (Herting \& Dely-Draskovits (1993), Ziegler \& Shima (1996), Richter (2004)].

\section{Gymnosoma rotundata (Linnaeus, 1758)}

Musca rotundata Linnaeus, 1758: 596. Type locality: not given.

Material examined: North Korea, Hamgjŏng-Pukto prov., Kjŏngsŏng County, Sang-onpori, 17.06.1990, 1 female, leg. E. Chudzicka, E. Kierych and R. Pisarska.

Distribution: Europe northwards to Ireland, England, Sweden and northern part of Russia; Asia: Transcaucasia, S. Siberia (Tuva, Altai, Tomsk Province, Novosibirsk Province), Russian Far East ( Amuria, Ussuria), Japan (Kyushu, to Hokkaido) (Herting \& Dely-Draskovits (1993), Ziegler \& Shima (1996), Richter (2004)].

Phasia Latreille, 1804

\section{Phasia (Phasia) aurulans Meigen, 1824}

Phasia aurulans Meigen, 1824: 197. Type locality (Austria).

Material examined: North Korea, Hamgjŏng-Pukto prov., Kjŏngsǒng County, Sang-onpori, 17.06.1990, 1 female, leg. E. Chudzicka, E. Kierych and R. Pisarska.

Distribution: Europe northwards to Belgium, Sweden and northern European part of Russia; Asia: N. Kazahstan, W. and S. Siberia (Altai, Tomsk, Krasnoyarsk, Irkutsk), Russian Far East (Amuria, Ussuria), Japan (Hokkaido) (Herting \& Dely-Draskovits (1993), Ziegler \& Shima (1996), Richter (2004)].

Tribe Leucostomatini

Dionaea Robineau-Desvoidy, 1830 


\section{Dionaea karinae sp. nov. (Figs 2-5)}

Type material. Holotype: male. Locus typicus: North Korea, Phjŏngan-pukto prov., Mjohjang-san Mts., near Mjohjang-san hotel, ravine, 11.06.1990, 1 male, leg. E. Chudzicka, E. Kierych and R. Pisarska. The holotype of the species is deposited in the collection of the Museum and Institute of Zoology of the Polish Academy of Sciences in Warsaw.

Etymology. This new species is dedicated to my granddaughter Karina Ziółkowska.
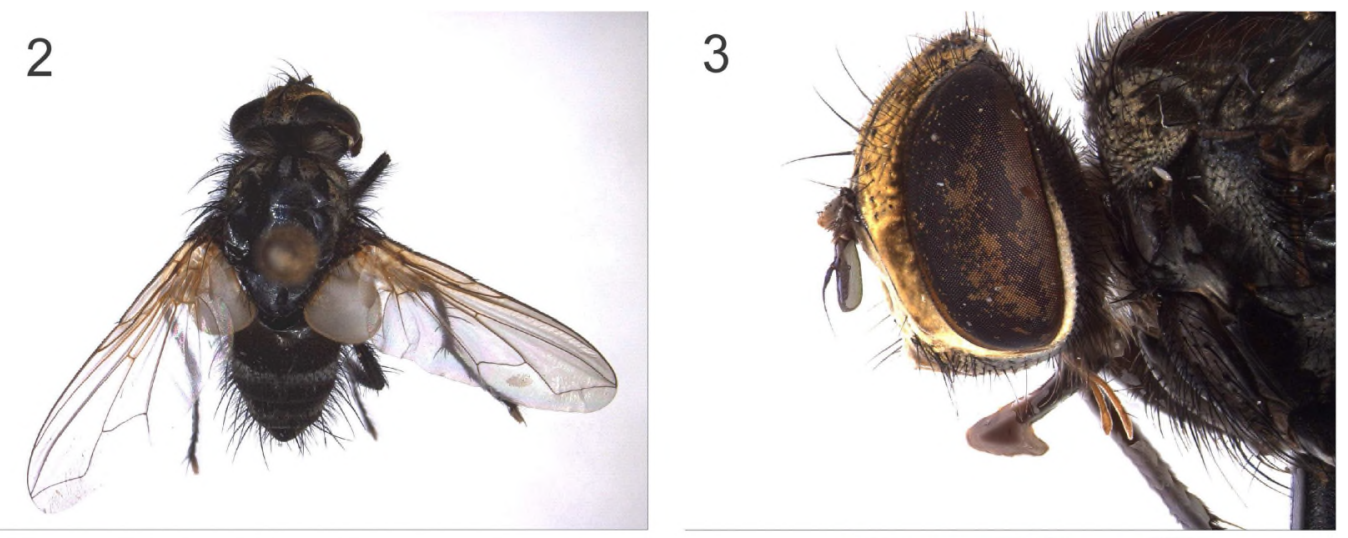

4

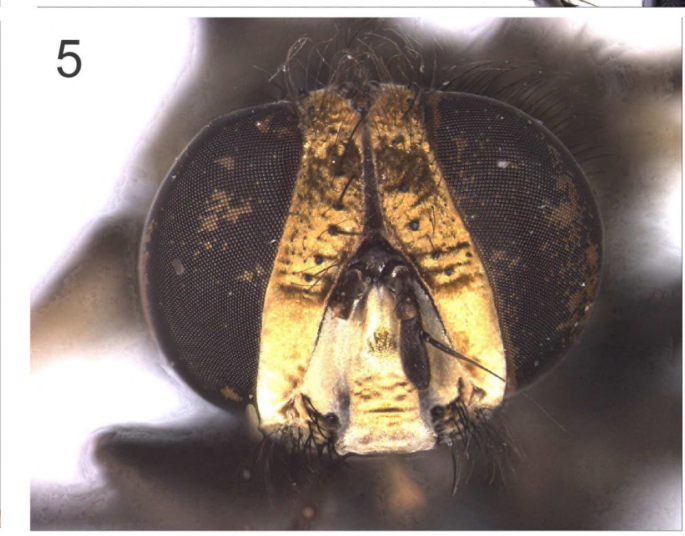

Figs 2-5. Dionaea karinae sp. nov., male, North Korea, Phjŏngan-pukto prov., Mjohjang-san Mts., near Mjohjang-san hotel, ravine, 11.06.1990, leg. E. Chudzicka, E. Kierych and R. Pisarska (photo P. Ślipiński): 2 - view from above, 3 head with antenna in profile, 4 - head in dorsal view, 5 - head in frontal view.

Description. Male. Body length $8.0 \mathrm{~mm}$. Black species densely golden silver pollinose on the dorsum of thorax, $3^{\text {rd }}$ to $5^{\text {th }}$ abdominal terga and golden pollinose on head.

Head (Figs 3-5). Fronto-orbital plate to occiput, parafacialia, central part of face and genal grove densely golden pollinose. Lateral part of face and postocular part of head (between ocular and postocular setae) silver-golden pollinose. On lower part of fronto-orbital plate and upper parafacialia three horizontal rugae. Frontal vitta very narrow, about 0.1 times as wide as fronto-orbital plate at middle, ocellar triangle, occupying almost posterior $1 / 3$ of frons, ocelli dark red. Occiput and median occipital plate black and silver grey dusted with black and white hairs and densely whitish pile. Frons at its narrowest point 0.23 of head width and 0.67 of single eye width. Face almost as long as frons in profile. Parafacial in position of head profile as wide as $1^{\text {st }}$ flagellomere at middle hight. Gena in position of head profile 0.09 of eye height. 
Inner vertical seta not long, outer vertical seta only slightly longer than postocular hairs, ocellar seta not strong, postocellar setae absent, 5-7 frontal setae, lowest seta nearly level with middle of pedicel, 1 reclinate orbital seta. Pedicel on apex light brown, several rows (3-4) of thin hairs present among frontal setae. The parafacial bare, the vibrissa not very strong, arising slightly above the level of the lower facial margin which is visible in profile, the facial ridge with 4 fine setae just above the vibrissa. Antenna with $1^{\text {st }}$ flagellomere 1.5 times as long as pedicel. Arista without pubescence, thickened on almost basal $0.25,2^{\text {nd }}$ aristomere almost twice as long as wide. Palpus orange light brown, narrow, 1.5 times longer than $1^{\text {st }}$ flagellomere. Eye bare, oval in lateral view.
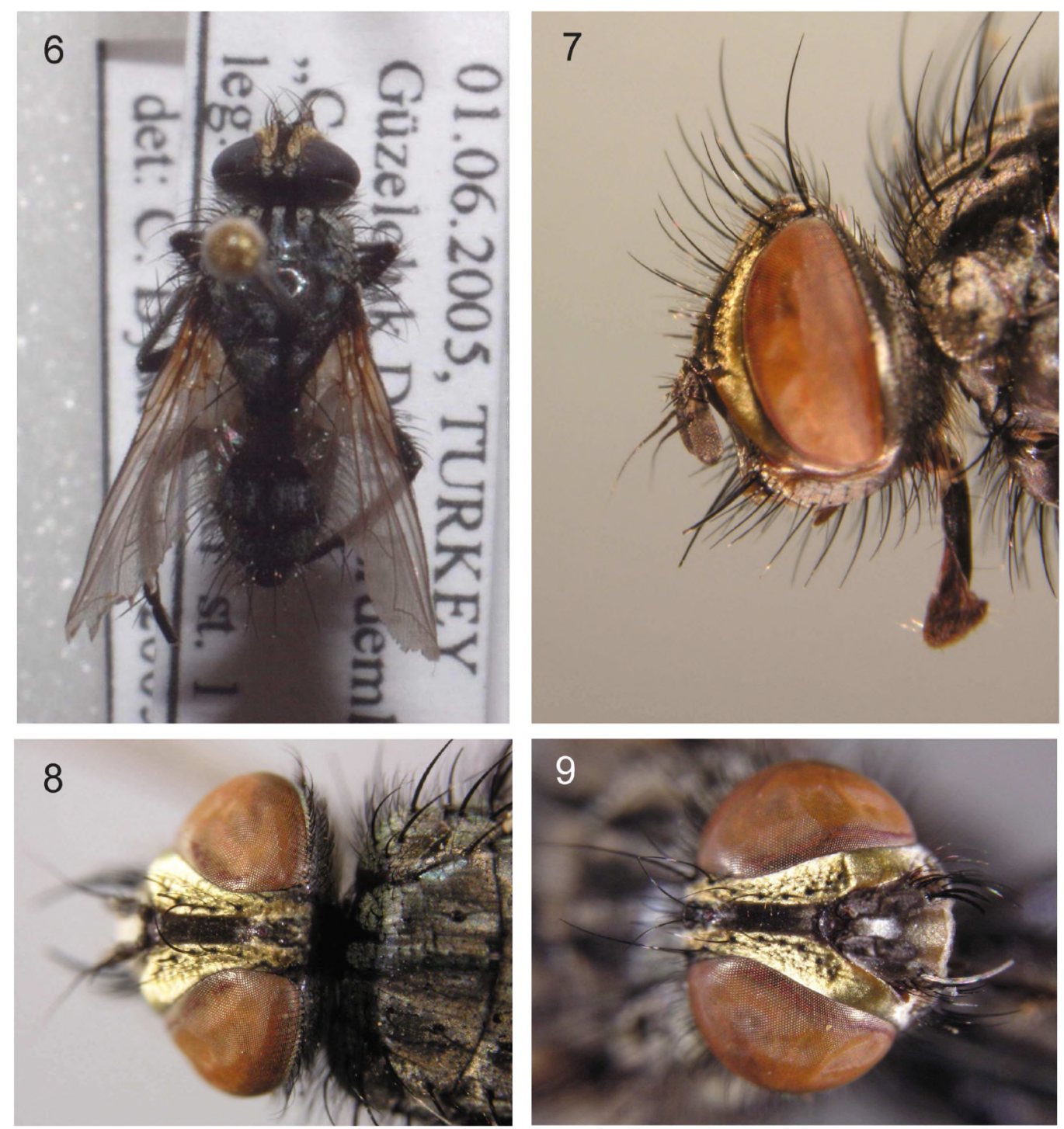

Figs 6-9. Dionaea aurifrons (Meigen), male, 6- Turkey, Güzeloluk, distr. Erdemli, "Cedry", 1.06.2005, leg. et det. C. Bystrowski; 7-9 - Spain, Gerona prov., 2-3 km S. Port de la Selva, 2. 06.1998, 1 male, leg. et det. H. P. Tschorsnig (photo C. Bystrowski); 6 - view from above, 7 - head with antenna in profile, 8 - head in dorsal view, 9 - head in frontal view. 
Thorax (Fig. 2). Black in ground colour, dorsum gold silver pollinose on postpronotal lobe, with 4 black longitudinal vittae, notopleural region narrow, posterior portion of presutural area along transverse suture and intra-alar region of postsutural scutum, pleura fine silvery grey pollinose. Hair erect and black; $1+1$ acrostichal setae, $2+3$ dorsocentral setae, $0+2$ intraalar setae, 2 supraalar setae, $2+3$ postpronotal setae arranged in a stright line, $2+1$ katepisternal setae. Scutellum black with fine grey pollinosity, with 3 pairs of strong marginal setae.

Wing (Fig. 2). Hyaline, base of wing yellow, tegula and basicosta black, halter yellow, lower calypter whitish with yellow border. Costal spine shorter than vein $r-m$. Vein $r 4+5$ with $1-2$ setulae at base dorsally and 1 ventrally, cell $R 4+5$ open.

Legs. Black, tibiae dark brown, pulvillae yellow. Claws and pulvillae longer than $5^{\text {th }}$ tarsomere. Fore tibia with 4 weak and short posterodorsal setae. Mid tibia with 2 long and some short anterodorsal setae, 5-6 short posterodorsal setae and 1 long and 1 short ventral setae. Hind tibia with 10 anterodorsal setae, 4 posterodorsal setae and 3 ventral setae. Hind femur with many very strong and long ventral and dorsal setae.

Abdomen (Fig. 2). Black in ground colour. Syntergum $1+2$ black without pollinosity. Dorsum silver pollinose on anterior $2 / 3$ of $3^{\text {td }}$ and $4^{\text {th }}$ terga and anterior $1 / 2$ of $5^{\text {th }}$ tergum, posterior black portion of $3^{\text {rd }}$ and $4^{\text {th }}$ terga triangularly expanded to anterior portion, mid dorsal longitudinal vitta weakly developed on $3^{\text {rd }}$ and $4^{\text {th }}$ terga, venter black without pollinosity, with many, long strong, black setae. Hair on dorsum rather dense, strong, long and suberect, long and strong on side of each tergum. Each tergum with row of strong and long marginal setae. $5^{\text {th }}$ tergum with irregular setae on the posterior half. Male genitalia not dissected.

Diagnosis. This new species is close to Dionaea aurifrons (Meigen, 1824), but may be easily distinguished from it by the narrow frontal vitta and genae, and by the number and position of frontal setae (Figs 6-9).

Clairvillia Robineau-Desvoidy, 1830

\section{Clairvillia biguttata (Meigen, 1824)}

Tachina biguttata Meigen, 1824: 320. Type locality: not given.

Material examined: North Korea, Phjŏngan-pukto prov., Mjohjang-san Mts., near Mjohjang-san hotel, ravine, 11.06.1990, 1 female, leg. E. Chudzicka, E. Kierych and R. Pisarska.

Distribution: Europe northwards to Belgium, Germany, Poland and northern European part of Russia; Asia: Transcaucasia, Levant, Mongolia, E. Siberia (Chita, Yakutia) and Russian Far East (Ussuria) (Herting \& Dely-Draskovits (1993), Ziegler \& Shima (1996), Richter (2004).

Tribe Cylindromyiini

Cylindromyia Meigen, 1803

Cylindromyia (Neocyptera) Townsend, 1916

\section{Cylindromyia (Neocyptera) arator Reinhard, 1956}

Cylindromyia arator Reinhard, 1956: 121. Type locality: Chang Hyon (S.Korea)

Cylindromyia lehri Kolomyetz, 1976: 158. Type locality: Komarovo, Primorie (Russian Far East)

Material examined: North Korea, Phjŏngan-pukto prov., Mjohjang-san Mts., 3.08.1959, 1 male, leg. B. Pisarski and J. Prószyński. 
Distribution: Asia: Mongolia, Russian Far East (Ussuria), Korea, China (Heilongjiang, Jiangsu, Sichuan, Zheijiang) (Herting 1983, Ziegler \& Shima 1996, Richter 2004), Kolomyetz 1976:158 recorded from Ussuria as C. lehri Kol.

\section{Cylindromyia (Malayocyptera) Townsend, 1926}

\section{Cylindromyia (Malayocyptera) agnieszkae Kolomyetz, 1977}

Cylindromyia agnieszkae Kolomyetz, 1977: 53. Type locality: Ussuriysk, Primorie (Russian Far East).

Material examined: paratypi: North Korea, Chŏngdžin-si prov., Kjŏngsŏng distr., Onpho-ri ad Chŏngdžin, 16.08.1959, 1 male; 18.08.1959, 1 male; 19.08.1959, 1 male, leg. B. Pisarski and J. Prószyński, det. N.G. Kolomyetz .

Distribution. Asia: Russian Far East (Primorie) (Kolomyetz 1977, Ziegler \& Shima 1996, Richter 2004), N. Korea (Kolomyetz 1977 and Kaesong (Herting 1983).

\section{Cylindromyia (Malayocyptera) umbripennis van der Wulp, 1881}

Ocyptera umbripennis van der Wulp, 1881: 35. Type locality: Surulangun (Sumatra).

Distribution. Palaearctic: Asia: Russian Far East (Primorie), Korea, Japan (Island Tsushima) (Herting 1983, Ziegler \& Shima 1996, Richter 2004), Oriental Region: $C$. umbripennis is widely distributed in this region, and has been recorded from Sri Lanka, Ceylon, Malaysia, Sumatra, Philippines, Islands Flores, Taiwan (Crosskey 1976, Herting 1983, Richter \& Markova 1999).

Hemyda Robineau-Desvoidy, 1830

\section{Hemyda dominikae sp.nov. (Figs 10-17)}

Type material. Holotype: female. Locus typicus: North Korea, Phjŏngan-pukto prov. Mjohjang-san Mts., at the foot of Hjangro Peak, 9-12.06.1990, 1 female, leg. E. Chudzicka, E. Kierych and R. Pisarska. The holotype of the species is deposited in the collection of the Museum and Institute of Zoology of the Polish Academy of Sciences in Warsaw.

Etymology. This new species is dedicated to my granddaughter Dominika Ziółkowska.

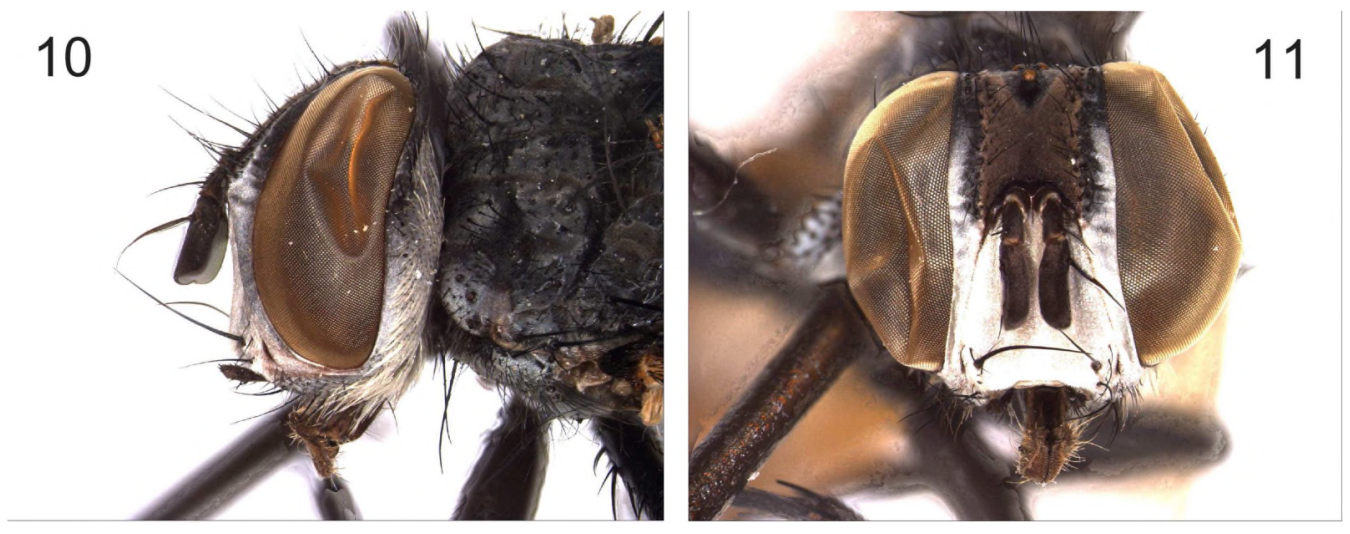

Figs 10-11. Hemyda dominikae sp. nov., female, North Korea, Phjōngan-pukto prov., Mjohjang-san Mts. at foot of Hjangro Peak, 9-12.06.1990, leg. E. Chudzicka, E. Kierych and R. Pisarska (photo P. Slipiński); 10 - head with forder part of thorax, 11 - head in frontal view. 

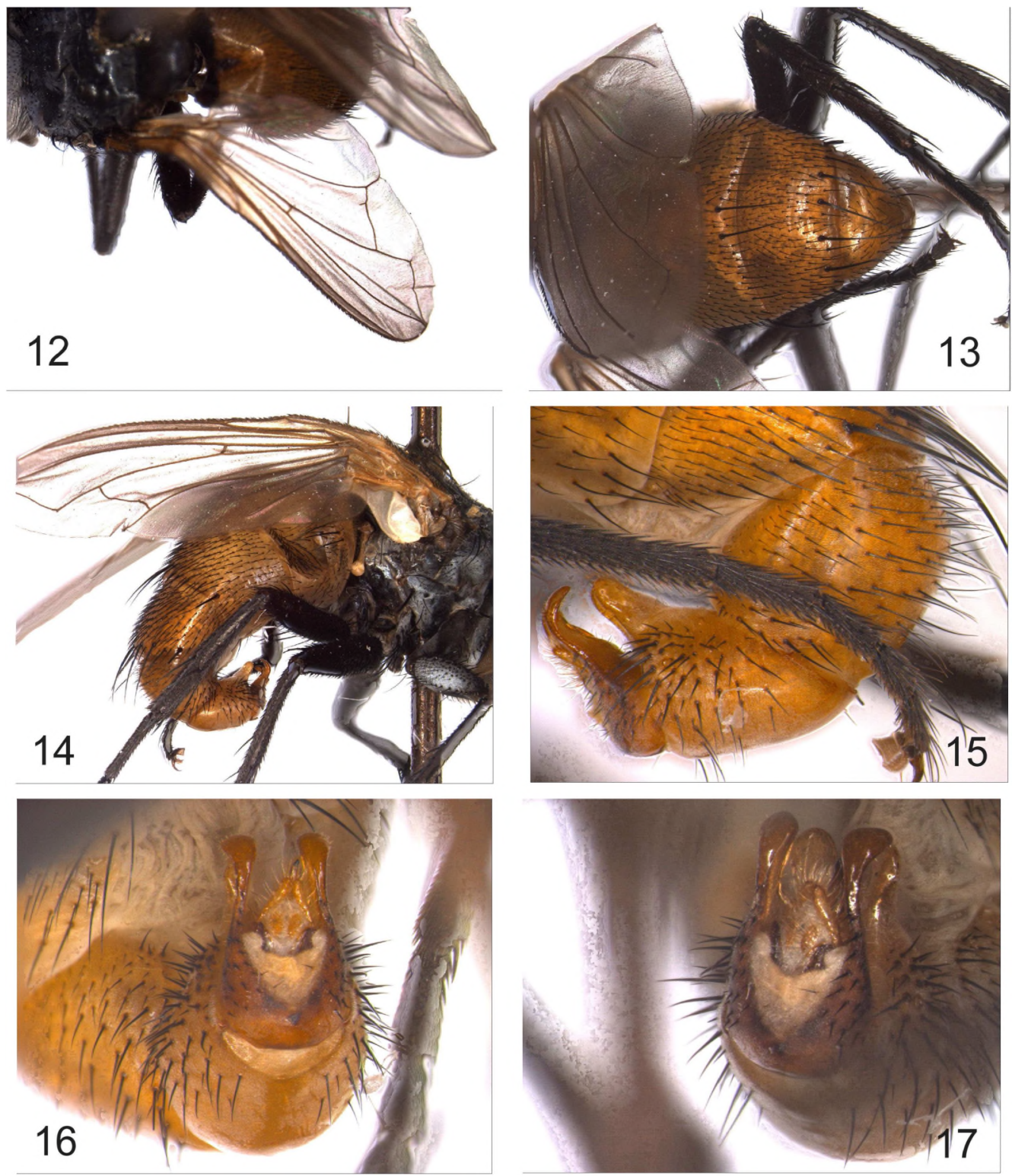

Figs 12-17. Hemyda dominikae sp. nov., female, North Korea, Phjŏngan-pukto prov., Mjohjang-san Mts. at foot of Hjangro Peak, 9-12.06.1990, leg. E. Chudzicka, E. Kierych and R. Pisarska (photo P. Ślipinski); 12 - wing in view from above, 13 - abdomen in dorsal view, 14 - abdomen in side view, 15 - postabdomen in profile, 16 - postabdomen in back view, 17 - postabdomen in side and back view.

Description. Female. Body length $9.0 \mathrm{~mm}$. Head (Figs 10-11). Fronto-orbital plate, parafacial, face, gena and occiput densely silver pollinose, narrow upper occiput and median occipital plate black. Frons at its narrowest point in front of ocellar triangle 0.37 of head width and 1.2 of single eye width. Frontal vitta broad, dark black deep red, velvety, about 4 times as wide as fronto-orbital plate before ocellar triangle. Ocellar triangle occupying almost posterior $1 / 3$ of frontal vitta. Ocellar triangle and its nearest triangular surroundings black and somewhat 
shining. Ocelli amber-coloured. Parafacial in position of head profile about 0.5 times as wide as $1^{\text {st }}$ flagellomere at middle height. Gena very narrow. Outer vertical seta undeveloped, hairlike, about as long as postocular hairs, inner vertical seta strong but broken, ocellar seta weak and broken too. 7 postocullar setae, their apices strongly bent forward. 2 strong proclinate orbital setae broken, 1 weak lateroclinate prevertical seta broken. 10-11 frontal setae, lowest seta nearly level with base of pedicel, several thin setae and long hairs present among them. Parafacials bare. Occiput with densely whitish long hairs and several short black setulae on upper portion. The vibrissa almost as long as face, arising slightly above the level of the lower facial margin, which is somewhat visible in profile, the facial ridge with 1-2 fine setae just above the vibrissa. Arista thickened on nearly basal $1 / 2,2^{\text {nd }}$ aristomere almost as long as wide. Palpus dark brown, apically thickened and lighted. Eye bare lightly reniform.

Thorax (Figs $10 \& 12$ ). Black in ground colour, dorsum greyish pollinose on postpronotal lobe, notopleural region, narrow posterior portion of presutural area along transverse suture and intraalar region of postsutural scutum. Pleura broadly silvery grey pollinose. Hair errect and setae black. $2+2$ acrostichal setae, $3+3$ dorsocentral setae, $0+2$ intraalar setae, 2 supraalar setae, 3 postpronotal setae, $1+1$ katepisternal seta. Scutellum black and very slightly greyish pollinose, with 3 pairs of marginal strong setae, basal setae short.
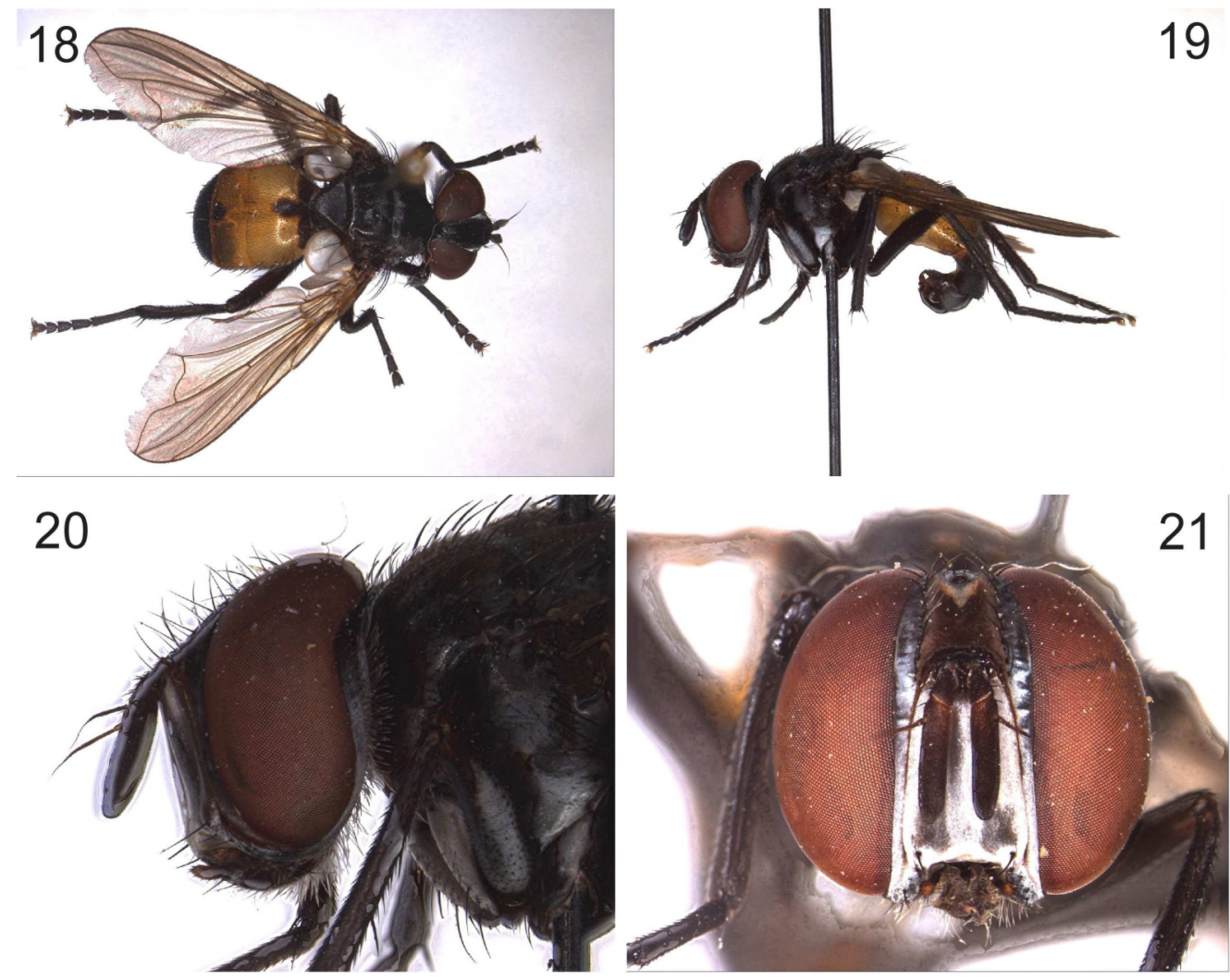

Figs 18-21. Hemyda obscuripennis (Meigen), female, Poland, Bizorenda, Jędrzejów distr., 5.07.1955, leg. J. Karczewski (photo P. Ślipinski); 18 - view from above, 19 - in side view, 20 - head in profile, 21 - head in frontal view. 

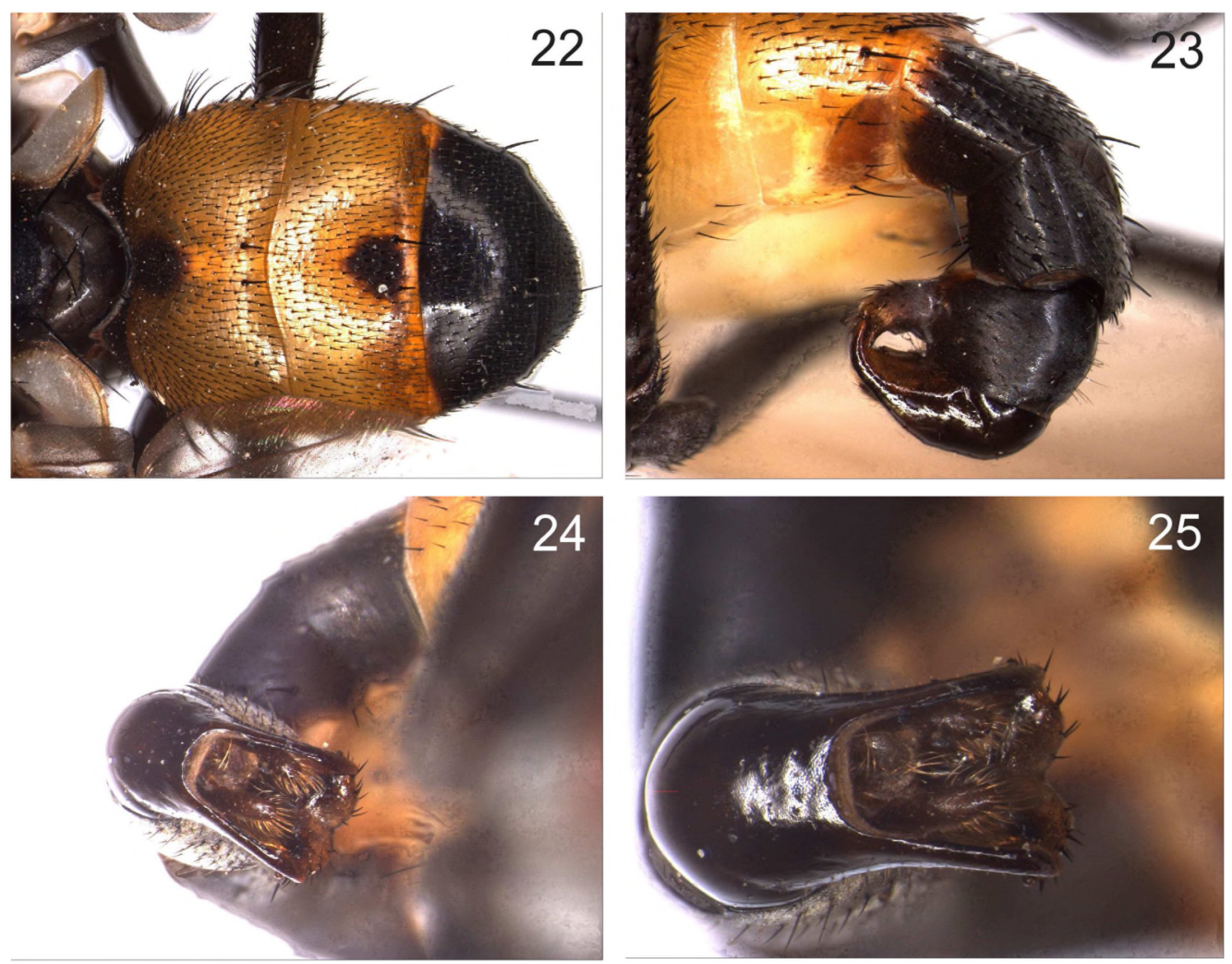

Figs 22-25. Hemyda obscuripennis (Meigen), female, Poland, Bizorenda, Jędrzejów distr., 5.07.1955, leg. J Karczewski (photo P. Ślipiński); 22 - abdomen in dorsal view, 23 - abdomen in profile, 24 - abdomen in ventral view, 25 - postabdomen in back view.

Wing (Figs 12 \& 14). Hyaline, evenly tinged with pale brown, lower calypter whitish, tegula black, basicosta yellow, halter yellow. Costal spine not differentiated, costa setulose below from base to apex of $3^{\text {rd }}$ costal sector. Vein $r$ 4+5 with $2-3$ very fine setulae at base dorsally and ventrally. Cell R $4+5$ open.

Legs. Femora and tarsi black, tibiae dark brown with strong setae. Fore tibia with 2 posterior setae. Mid tibia with 1 anterodorsal seta, 2 posterodorsal setae and 1 ventral seta. Hind tibia with 2 anterodorsal setae, 2 posterodorsal setae and 2 ventral setae. Claws on all legs shorter than $5^{\text {th }}$ tarsomere.

Abdomen orange yellow, without pollinosity, shiny, $5^{\text {th }}$ tergum strongly curved anteroventrally (Figs $13 \& 15$ ). Spinulae black and decumbent on $1 \mathrm{st}+2 \mathrm{nd}, 3^{\text {rd }}$ and $4^{\text {th }}$ terga and erect on $5^{\text {th }}, 6^{\text {th }}$ and $7^{\text {th }}$. Discal setae absent. 1 pair median and 1 each lateral marginal setae on syntergum 1+2; 1 pair median and 1 each lateral marginal setae and row of long hair-like setae on $3^{\text {rd }}$ tergum; row of 7 marginal setae and row of long hair-like marginal setae on $4^{\text {th }}$ tergum, and 2 short marginal setae on $5^{\text {th }}$ tergum (Fig. 13).

Postabdomen (Figs 14-17). Syntergum $6+7$ almost as long as $5^{\text {th }}$ tergum, with special fork ventrally. Syntergum $6+7$ with many strong, short and erect setae.

Diagnosis. This new species is close to Hemyda obscuripennis (Meigen, 1824) but may be easily distinguished from it by the width of the vertex (Figs $18 \& 21$ ), the frontal vitta, a less 
indented hind margin of the eye and an orange yellow abdomen. The female genitalia of this new species are very different from those of H. obscuripennis, as shown in Figs $19 \& 23-25$.

\section{ACKNOWLEDGEMENTS}

I should like to express my most cordial thanks to Dr Cezary Bystrowski and Mr Piotr Ślipiński, MSc. (Eng.) in Environmental Protection, for taking the photographs. Special thanks to Mr Tomasz Karolkiewicz for the digital prepararation of the figures. I am also grateful to Professors M. Chvala and R. Szadziewski for their valuable comments.

\section{REFERENCES}

ALDRICH J. M. 1928. Five new parasitic flies reared from beetles in China and India. Proceedings of the United States National Museum. Smithsonian Institution 76: 1-13.

BANKOWSKA R. \& STERZYISSKA M. 1997. Faunistic investigations conducted in North Korea by researchers from the Institute of Zoology Polish Academy of Sciences from 1959 to 1990. Fragmenta Faunistica, Warszawa, 40:247-253.

BARANOV N. 1932 a. Neue orientalische Tachinidae. Encyclopédie entomologique. Ser. B. II, Diptera 6: 83-93.

BARANOV N. 1932 b. Zur Kenntnis der formosanischen Sturmien (Dip., Larvaevor.). Neue Beiträge zur systematischen Insektenkunde 5: 70-82.

BARANOV N. 1932 c. Zur Kenntnis der orientalischen Dexia-ähnlichen Arten. (Dipt. Larvaevor.). Wiener entomologiche Zeitung 49: 212-216.

BARANOV N. 1934 a. Zur Kenntnis der parasitären Raupenfliegen der Salomenen, Neubritanniens, der AdmiralitätsInseln, der Fidschi-Inseln und Neukaledoniens, nebst einer Bestimmungstabelle der orientalischen Sturmia-Arten. Veterinarski Arhiv 4: 472-485.

BARANOV N. 1934 b.Übersicht der orientalischen Gattungen und Arten des Carcelia-Komplex (Diptera Tachinidae). Transactions of the Royal Entomolgical Society of London 82: 387-408.

BARANOV N. 1934 c. Neue Gattungen und Arten der orientalischen Raupenfliegen (Larvaevoridae). Encyclopédie entomologique. Ser. B. II, Diptera 7: 160-165.

BARANOV N. 1935. Neue paläarktische und orientalische Raupenfliegen (Dipt., Tachinidae). Veterinarski Arhiv 5: $550-560$

BARANOV N. 1936. Weitere Beiträge zur Kenntnis der parasitären Raupenfliegen (Tachindae=Larvaevoridae) von den Salomonen und Neubritanien. Annals and Magazine of Natural History 17: 97-113.

BARANOV N. 1938. Neue Indo-Australische Tachinidae. Bulletin of Entomological Research 29 (4): $405-414$.

BARANOV N. 1952. A contribution to the study of the zoo-geographic relations of the Islands Hokkaido (Japan). Pakistan Journal of Science 4: 118-120.

BECKER Th. \& SCHNABL J. 1926. Dipteran von W. W. Sowinsky an der Ufern des Baikal-See im Jahre 1902 gesammelt. (Wissenschaftliche Ergebnisse einer Zoologischen Expedition nach dem Naikal-SEE unter der Leitung des Professors Alexis Korotneff). Entomologische Mitteilungen 15: 33-46.

BEZZI M. 1925. Some Tachinidae (Dipt.) of economic importance from the Federated Malay States. Bulletin of Entomological Research 16: 113-123.

Borisova-ZINOVEVA K. B. 1962. On two new species of the genus Nemosturmia T. T. (Diptera, Larvaevoridae) from the Far East. Trudy Zoologicheskogo Instituta Akademii Nauk SSSR 30: 326-329.

BorISOVA-ZINOVEva K. B. 1966 a. New species of the genus Hyperecteina Schiner (Diptera, Larvaevoridae). Trudy Zoologicheskogo Instituta Akademii Nauk SSSR 37: 272-276.

Borisova-ZINOVEVA K. B. 1966 b. On some species difficult to distinguish belonging to the genus Hyperecteina Schiner (Diptera, Larvaevoridae). Acta Entomologica Bohemoslovaca 63: 420-439.

CANTRELl B. K. \& CRosskey R. W. 1989. 113. Family Tachinidae, pp. 733-784. In: EvenNius N. L. (ed), Catalog of the Diptera of the Australasian and Oceanian Regions. Bishop Museum Special Publication 86. Bishop Museum Press and E .J .Brill. Honolulu, Hawaii, 1155 pp.

CHAO C. M. 1962 a. Notes on Tachinid (Larvaevoridae) fauna of China. I. Linnaemyia R.-D. Acta Entomologica Sinica 11: 83-98.

CHAO C. M. 1962 b. Notes on Tachinid (Larvaevoridae) fauna of China. II. Servillia R.-D. Acta Entomologica Sinica 11(Suppl.): 45-65.

CHAO C. M.1963. Notes on Tachinid (Larvaevoridae) fauna of China. III. Description of a new species, parasitic on oak (Chinese) silikworm in N.E. China. Acta Entomologica Sinica 12: 37-40.

CHAO C. M. 1964 a. Fauna Larvaevoriden Chinas. V.Gattung Exorista Meigen. Acta Entomologica Sinica 13: 362375 .

CHAO C. M.1964 b. Notes on the Chinese Larvaevoridae.VI. Phorocera R.-D. Acta Zootaxonomica Sinica 1: $293-297$.

CHAO C. M. 1965. Fauna Larvaevoriden Chinas. VIII. Gattung Chaetexorista B. B. Acta Zootaxonomica Sinica 2: $101-105$. 
CHAO C. M. 1974. Notes on the Chinese Larvaevoridae. IX. Hystromyia Portschinsky, Acta Entomologica Sinica 17: $474-478$.

CHAO C. M. 1976. New species of the genus Thecocarcelia T. T. (Diptera, Tachinidae). Acta Entomologica Sinica 19: 335-338

CHAO C. M. 1979. New species of Tachinidae (Diptera) from Mount Tomuer, Xinjing, China. Entomotaxonomia 1: 79-82.

CHAO C. M. 1998. Tachinidae. pp.1661-2206. In: XUE W. Q. \& CHAO C. M. (eds). Flies of China.Vol. 2. Liaoning Science and Technology Press. Shenyang. $2425 \mathrm{pp}$.

ChaO C. M., Liang E. Y., SHI Y. S. \& ZHou S. X. 2001. Fauna Sinica, Insecta. Vol. 23, Diptera Tachinidae (1) Science Press, Beijing, 305 pp.

CHAO C. M. \& LIANG E. 1980. Notes on new species of Chinese Erycilla Mesnil (Diptera, Tachinidae). Zoonoses Research 3: 77-81.

CHAO C. M. \& SHI Y. S. 1981. Notes on the new genus Flavicorniculum Chao et Shi of Tachinidae from China. Acta Entomologica Sinica 24: 203-208.

Coquiliett D. W. 1910. The type-species of the North American genera of Diptera. Proceedings of the United States National Museum 37: 499-647.

CRosskey R. W. 1966 a. Generic assignment and synonymy of Wiedemann's types of Oriental Tachinidae (Diptera). Annals and Magazine of Natural History (13) 8 (1965): 661-685.

CROSSKEY R. W. 1966 b. New generic and specific synonymy in Australian Tachinidae (Diptera). Proceedings of the Royal Entomological Society of London, (B) 35: 101-110.

CROSSKEY R.W. 1967 a. An index-cataloge of the genus-group names of Oriental and Australasian Tachinidae (Diptera) and their type-species.Bulletin of the British Museum (Natural History) Entomology 20: 1-39.

CROSSKEY R. W. 1967 b. New generic and specific synonymy in Oriental Tachinidae (Diptera). Proceedings of the Royal Entomological Society of London, (B) 36: 95-108.

CRosskey R. W. 1969. The type-material of Indonesian Tachinidae (Diptera) in the Zoological Museum, Amsterdam. Beaufortia 16: 87-107.

CRosskey R. W. 1976. A taxonomic conspectus of the Tachinidae (Diptera) of the Oriental Region. Bulletin of the British Museum Natural History, Suppl., 26: 1-357.

CRosskey R. W. 1977. Family Tachinidae, pp.586-697. In: DelFINADO M. D. \& HARdy D. E. (eds), A Catalog of the Diptera of the Oriental Region. The University Press of Hawaii. Honolulu, 854 pp.

CRosskey R.W. 1980. Family Tachinidae, pp.822-885. In: CRosskey R. W. (ed.), Catalog of the Diptera of the Afrotropical Region. British Museum (Natural History), London, $1437 \mathrm{pp}$.

CtrRan C. H. 1927. Some new Australasian and African Diptera of the families Muscidae and Tachinidae (Dipt.). Entomologische Mitteilungen 16: 345-357.

CuRRAN C. H. 1934. The families and genera of North American Diptera. Ballou Press, New York, 512 pp.

CtrRan C. H. 1938. New species and records of Tachinidae (Diptera). Proceedings of the Linnean Society of New South Wales 63: 185-206.

DRABER-MoNko A. 1965. Monographie der paläarktischen Arten der Gattung Alophora R.-D. (Diptera, Larvaevoridae). Annales Zoologici 23: 70-104.

DUPUIS C. 1961. Contributions à l' étude des Phasiinae cimicophages. XXIV. Les Gymnosoma ouest-paléarctiques (à 1' exclusion du groupe de costata Pz.). Cahier des Naturalistes 16: 69-76.

FABRICIUS J. C. 1794. Entomologia systematica emendata et aucta. Secundum classes, ordines, genera, species adjectis synonimis, locis, observationibus, descriptionibus. 4. Hafniae [=Copenhagen], $472 \mathrm{pp}$.

HAN H.Y. \& KIM C. W. 1983. The Korean flies of the Tribe Tachinini (Diptera: Tachinidae). Entomological Research Bulletin 9: 77-94.

HERTING B. 1983 a. 64 c. Phasiinae. In: LINDNER E. (ed.): Die Fliegen der palaearktischen Region 9: 1-88. Stuttgart: E. Schweitzerbart'sche Verlagbuchhandlung.

HeRTing B. 1983 b. Catalogue of Palearctic Tachinidae (Diptera). Stuttgarter Beiträge zur Naturkunde. Serie A (Biologie) No. 369: 1-228

Herting B. \& Dely-Draskovits Á. 1993. Family Tachinidae.Vol.13, pp. 118-458. In: Soós Á. (ed.), Catalogue of Palaearctic Diptera, Anthomyiidae - Tachinidae. Hungarian Natural History Museum, Budapest, 624 pp.

Hitzova L. N. 1975. O faunie fazii (Diptera, Tachinidae) Altajskovo zapoviednika i ego okresnostej. In: book: Problemy izucheniya i ochrany i landshchaftov. 2-j mezhvyzovskij sbornik: 60-62.

Hitzova L. N. \& VINOKUROV N. N. 1977. Preimaginalnye fazy nekotorykh takhin roda Gymnosoma (Diptera, Tachinidae), parazitiruyushchikh na klopakh v Jakutii. Zoologicheski Zhurnal 56:310-313.

JACOBSON G. 1899. De specie nova generis Phasia (Diptera, Muscidae). Annuaire du Musée zoologique de 1'Academiémie (Impériale) des Sciences de St.-Pétersburg Russie 4: 297-299.

KAMENKova K. V. 1956. Diptéres (Diptera, Phasiidae) parasites de punaises de la famille Pentatomidae du cercle de Krasnodar. Èntomologicheskoe Obozrenie 35: 324-333.

KocHA T. 1969. On the Japanese species of the genus Nemorea Robineau-Desvoidy, with descriptions of two new species (Diptera, Tachinidae). Kontyû 37: 344-354. 
Kocha T. 1971. A new species of the genus Smidtiola Mesnil from Japan (Diptera: Tachinidae). Kontyû 39: 292-293.

Kolomyetz N. G. 1952. Novyj vid roda Masicera iz Sibiri (Diptera, Larvaevoridae) - parazit sibirskogo shelkopryada. Zoologicheski Zhurnal 31: 297-304.

Kolomyetz N. G. 1966. Parasitic Diptera of subfam. Dexiinae (Dipt. Larvaevoridae). Genara Phorostoma and Billaea in the fauna of the USSR. Novye i maloizvestnye vidy fauny Sibiri 1966: 57-104.

Kolomyetz N. G. 1967. The review of parasitic Diptera of the genus Eriothrix Mg. (Diptera, Tachinidae) from the fauna of the USSR. Èntomologicheskoe Obozrenie 46: 241-258.

Kolomyetz N. G. 1970. Parasitic Diptera of the genus Dexia Mg. (Diptera, Tachinidae) of the USSR fauna. Novye i maloizvestnye vidy fauny Sibiri 3: 53-76.

KolomyetZ N. G. 1971. The parasitic Diptera of the genus Zeuxia Mg. (Diptera, Tachinidae) in the USSR fauna. Novye i maloizvestnye vidy fauny Sibiri 4: $28-61$.

KolomyetZ N. G. 1973 a. Parasitic Diptera of the genus Myiostoma R.-D. (Diptera, Tachinidae) from the USSR fauna. Novye i maloizvestnye vidy fauny Sibiri 6: 85-95.

Kolomyetz N. G. 1973 b. Parasitic Diptera of the genus Trixa Mg. (Diptera, Tachinidae) from the USSR fauna. Novye i maloizvestnye vidy fauny Sibiri 7: 102-111.

Kolomyetz N. G. 1974 a. Parasitic Diptera of the genus Dolichodexia Brauer et Bergenstamm (Diptera, Tachinidae) from the USSR fauna. Novye i maloizvestnye vidy fauny Sibiri 8: 95-103.

KolomyetZ N. G. 1974 b. Materialy po faune i biologii Deksij (Diptera, Tachinidae) Sibiri i Dal'nego Vostoka, pp. 132-153. Fauna i ekologiya nasekomyh Sibiri. Izdatelstvo "Nauka". Sibirskoe Otdelenie.

Kolomyetz N. G. 1975. Evidence on the fauna and biology of parasitic Diptera of the subfamily Tachininae (Diptera, Tachinidae) in Siberia and the Soviet Far East. Entomofagi Sovetskogo Dal'negoVostoka.Trudy Biologopochvennogo instituta, nov. ser., 27 (130): 21-46.

KOLOMYETZ N. G. 1976. Obzor dvukrylykh podsemeystva fazij (Diptera, Tachinidae, Phasiinae) fauny Sibiri i Dal'nego Vostoka. Nasekomye Dal'nego Vostoka. Trudy Biologo-pochvennogo instituta, Nov. ser., 43 (146): $143-164$

Kolomyetz N. G. 1977a. New data on the parasitic Diptera Phasiinae from Siberia and the Far East. Izvestiya Sibirskogo Otdeleniya Akademii Nauk SSSR 3: 52-55.

KOLOMYETZ N. G. 1977b. Materials on the fauna and biology of parasitic Diptera of the subfamily Exoristinae (Diptera, Tachinidae) in Siberia and the Soviet Far East. Fauna i biologia nasekomykh Dal'nego Vostoka. Trudy Biologo-pochvennogo instituta, nov. ser., 44 (147): 35-80.

KOLOMYETZ N. G. 1979. Redkie i maloizvestnye paraziticheskie dvukrylye v faune Sibiri i Dal'nego Vostoka. Ekologia i biologia chlenistonogikh yuga Dal'nego Vostoka: 138-145.

KOLOMYETZ N. G. 1987 a. Insects-parasites and predators of the gypsy moth (Lymantria dispar L., Lepidoptera) from the Asiatic part of the USSR. Izvestiya Sibirskogo Otdeleniya Akademii Nauk SSSR, ser. biol., 1: 83-89.

Kolomyetz N. G. 1987 b. Tachinid flies (Diptera, Tachinidae) as effective parasites in forests of northern Asia. In: Diptera and their importance for animal husbandry and agriculture. USSR Academy of Sciences Zoological Institute, $158 \mathrm{pp}$.

KOLOMYETZ N. G. 1989. Insects-parasites and predators of the pine moth (Dendrolimus pini L., Lepidoptera) of the USSR. Izvestiya Sibirskogo Otdeleniya Akademii Nauk SSSR, ser. biol., 1: 70-77.

KOLOMYETZ N. G. 1990. Insects-parasites and predators of the gypsy moth (Lymantria dispar L., Lepidoptera) in USSR. Chlenistonogie i gel'minty. Akademia Nauk SSSR Sibirskoe Otdelenie, Biologicheskij Institut: $242-251$.

KolomyetZ N. G. 1992. The Ichneumonid, Braconid and Tachinid parasites associated with forest pests in west Siberia. Sibirskij biologicheskij Zhurnal 1: 50-53.

Kolomyetz N. G .\& Bogdanova D. A.1980. Parazity i khishchniki ksilofagov Sibiri. Izdatelstvo "Nauka", Sibirskoe Otdelenie, $277 \mathrm{pp}$.

LINNAEUS C. 1758. Systema Naturae per regna tria naturae, secundum classes, ordines, genera, species, cum caracteribus, differentiis, synonymis, locis. 1. Ed. 10, Holmie [= Stockholm], 824 pp.

LOEW H. 1844. Zur Kenntnis der Ocyptera-Arten. Stettiner entomologische Zeitung 5: 226-240, 266-269.

LOEW H. 1845. Noch einige Bemerkungen über die Gattungen Ocyptera. Stettiner entomologische Zeitung 6: 170-183

LOEW H. 1847. Einige neue Tachinarien. Stettiner entomologische Zeitung 8: 259-276.

LOEW H. 1858. Beschreibung einiger japanischer Dipteren. Wiener entomologische Monatsschrift 2: 100-112.

MACQUART J. 1843. Diptères exotiques nouveaux ou peu connus. Mémoires de la Societe des Sciences de l'Agriculture, Lille, 1842: 162-460.

MACQUART J. 1845. Nouvelles observations sur les Diptères de la tribu des Tachinaires. Annales de la Société entomologique de France 3: 237-296.

MACQUART J. 1847. Diptères exotiques nouveaux ou peu connus. 2e Supplément. Mémoires de la Societe des Sciences de l'Agriculture, Lille, 1846: 21-120.

MACQUART J. 1851. Diptères exotiques nouveaux ou peu connus. Suite du 4e Supplément publié dans les Mémoires de la Société Royale des Sciences, de l'Agriculture et des Arts de Lille, 1850: 134-249.

MALLoch J. R. 1930. Notes on Australian Diptrera XXIII. Proceedings of the Linnean Society of New South Wales 55: $92-135$. 
MALLOCH J. R. 1934. New species of Diptera from China. The Peking Natural History Bulletin 9: 147-150.

MARKOVA T. O. 1999. New host and dustribution data of tachinid flies of subfamily Phasiinae (Diptera, Tachinidae) in Siberia and Russian Far East. Far Eastern Entomologist 75: 1-8.

MARKOVA T. O. 2000 a. Ecological and faunistic patterns of tachinid flies of subfamily Phasiinae (Diptera, Tachinidae) of Ussuriyskiy Nature Reserve and adjacent territory. A. I. Kurentsov's Annual Memorial Meetings 9: $33-48$.

MARKOVA T. O. 2000 b. The parasite-host relationships between the tachinid flies (Diptera, Tachinidae, Phasiinae) and bugs Dolycoris baccarum L. and Graphosoma rubrolineatum Westw. (Heteroptera, Pentatomidae). Khteniya Pamyati Alekseya Ivanovicha Kurentsova 10: 53-59.

MARKova T. O.\& LuTCHENKo V. A. 2001. Novye svedeniya o rasprostranenii v Primorskom Krae i khozyaevakh Perigymnosoma globula Vill. (Diptera, Tachinidae, Phasiinae). Poisk molodykh. Sbomik nauchnykh statej aspirantov, Ussuriysk, 3: 149-150.

Markova T. O., Lutchenko V. A. \& Hihluha V. A. 2002. K dannym o pishchevoj specyalizacij lichinok mukhtakhin (Diptera, Tachinidae) podsemejstva Phasiinae v Primorskom Krae. Zhivotny i rastitel'ny mir Dal'nego Vostoka 6: 44-50.

MATSUMURA S. 1904. Thousand insects of Japan. Tokyo.1. $114 \mathrm{pp.}$

MATSUMURA S. 1911. Erster Beitrag zur Insekten-Fauna von Sachalin. Journal of the College of Agriculture. Imperial University Tokyo, 4: 1-145.

MATSUMURA S. 1916. Thousand insects of Japan. Tokyo, Add. 2: 185-474.

MATSUMURA S. 1931. 6000 Illustrated insects of Japan-Empire. Tokyo, $1548 \mathrm{pp}$.

MEIGEN J. W. 1824. Systematische Beschreibung der bekannten europäischen zweiflügeligen Insektem. 4. Hamm,: $\mathrm{XII}+428 \mathrm{pp}$

MEIJERE de J. C. H. 1917. Studien über südostasiatische Dipteren. XIII. Ueber einige merkwürdigen javanischen Dipteren. Tijdschrift voor Entomologie 60: 238-251.

MESNIL L. P. 1942. Deux nouveaux Larvaevoridae du Mandchoukouo. Arbeiten über morphologische und taxonomische Entomologie Berlin-Dahlem, 9: 288-292.

MESNIL L. P. 1944-1975. 64g. Larvaevorinae (Tachininae). In: Lindner E. (ed.), Die Fliegen der palaearktischen Region 10 (1-3): 1-1435.

Mesnil L. P. 1953 a. Nouveaux Tachinaires d' Orient. (1e partie). Bulletin et Annales de la Société entomologique de Belgique 89: $85-158$.

Mesnil L. P. 1953 b. Nouveaux Tachinaires d' Orient. (2e partie). Bulletin et Annales de la Société entomologique de Belgique 89: 146-178.

MESNIL L. P. 1957. Nouveaux Tachinaires d' Orient. (deuxième série). Mémoires de la Société Royale d' Entomologie de Belgique 28: 1-80.

MESNIL L. P. 1963. Nouveaux Tachinaires de la region palaearctique, principalement de 1'URSS et du Japon. Bulletin de l' Institut royal des sciences naturelles de Belgique 39 (24): 1-56.

Mesnil L. P. 1968. Nouveaux Tachinaires d' Orient. (Troisième série). Bulletin et Annales de la Société entomologique de Belgique 104: 173-188.

MESNIL L. P. 1970. Descriptions de nouveaux Tachinaires de l'ancien monde, et notes synonymiques (Dipt. Tachinidae). Mushi 44: 89-123.

MESNIL L. P. 1971. Quelques nouveaux Tachinaires (Dipt. Tachinidae) de de l'ancien monde. Entomophaga 16: 67-73.

MESNIL L. P.\& PSCHORN-WALCHER H. 1968. A preliminary list of Tachinidae (Diptera) from Japan. Mushi 41: $149-173$.

MESNIL L. P.\& SHIMA H. 1977. A new genus and species of the Japanese Tachinidae (Diptera) reared from the nest of a solitary wasp Symmorhus sp. (Hymenoptera, Vespidae). Kontyû 45: 36-42.

MESNIL L. P. \& SHIMA H. 1978. New and little known Tachinidae from Japan (Diptera). Kontyû 46: 312-328.

Mesnil L. P.\& ShIMA H. 1979. New tribe, genera and species of Japanese and Oriental Tachinidae (Diptera), with note on synnymy. Kontyû $47: 476-486$.

MroczKowsKi M. 1972. Field Investigations in the Democratic People's Republic of Korea by staff members of the Institute of Zoology of the Polish Academy of Sciences. Fragmenta Faunistica, Warszawa, 18: 313-331.

REINHARD H. J. 1956. New Tachinidae (Diptera). Entomological News, 67: 121-129.

RTCHTER V. A. 1976 a. Zoogeographical features of the fauna of Tachinids (Diptera, Tachinidae) of Mongolia. Èntomologicheskoe obozrenie 55: 319-331.

RTCHTER V. A. 1976 b. The Tachinidae (Diptera) of the Mongolian People's Republic. Insects of Mongolia 4: 529-595.

RICHTER V. A. 1977. New data on the Tachinid fauna of Mongolia and southern Siberia. Insects of Mongolia 5: $731-736$.

RICHTER V. A. 1979. A new species of Tachinidae of the genus Rondania Rob.-Desv. (Diptera, Tachinidae) from Mongolia. Insects of Mongolia 6: 498-501.

RICHTER V. A. 1980. Tachinids (Diptera, Tachinidae) of the Chita region. Insects of Mongolia 7: 518-552.

RICHTER V. A. 1981. A new species of the genus Campylochaeta Rd. (Diptera, Tachinidae) from the Kuril Islands. Trudy zoologicheskogo Instituta 92: 136-138. 
RICHTER V. A. 1982. A new genus and species of Tachinidae (Diptera) from middle Asia. Trudy zoologicheskogo Instituta 110:109-112.

RTCHTER V. A. 2002. New data on the fauna of tachinids (Diptera, Tachinidae) of the Subpolar Urals and Russian Far East. Entomologicheskoe Obozrenie 81: 923-929.

RICHTER V. A. 2003. On the fauna of tachinids (Diptera, Tachinidae) of the Russian Far East. Entomologicheskoe Obozrenie 82: 917-921.

RICHTER V. A. 2004. Fam. Tachinidae - tachinids, pp. 148-398. In: SIDORENKo V. S. (ed.), Key to the insects of Russian Far East. Vol. VI. Diptera and Siphonaptera. Part 3. Vladivostok, Dal'nauka. 657 pp.

RICHTER V. A.\& MARKova T. O. 1999. The tachinid species Cylindromyia umbripennis van der Wulp new to the fauna of Russia (Diptera: Tachinidae). Zoosystematica Rossica 8: 188.

RTCHTER V. A. \& WOOD M. 1995. Tachinidae (Diptera) from Yakutia, with description of two new species. Acta Zoologica Fennica 199: 37-48.

RichTER V. A. \& WOOD M. 2003. Tachinids from Kamchatka (Diptera, Tachinidae). Zoosystematica Rossica 12: 277-278.

ROHDENDORF B. B. 1923. Zur Kenntnis der Gattung Syntomogaster Sch. Zoologischen Anzeiger 57: 24-28.

ROHDENDORF B. B. 1924a. Eine neue russische Phasiinen-Gattung. (Dip.). Entomologische Mitteilungen 13: $125-126$.

ROHDENDORF B. B.1924b. Eine neue Tachiniden-Gattung aus Turkestan. Zoologischen Anzeiger 58: 228-231.

ROHDENDORF B. B. 1927. Kurze Uebersicht der paläarktischen Salmacia Mg.1800 (Gonia Mg) Arten, nebst der Beschreibung einer neuen Art. Aus Turkestan (Diptera, Tachinidae). Russkoe èntomologicheskoe obozrěnie 21: 91-95.

ROHDENDORF B. B. 1928. Beiträge zur Kenntnis der Salmacia- (Gonia-) Gruppe. (Diptera, Tachinidae). Zoologischen Anzeiger 78: 97-102.

ROHDENDORF B. B. 1933 a. Charakteristik der Larvivoriden - Fauna der Gouvernements Moskau, auf Grund einer analyse der Phasiinen- Arten. Zoologicheski Zhournal 12: 117-120.

ROHDENDORF B. B. 1933 b. Larvivoridae (= Tachinidae) pp. 588-713, Phasiinae 705-713. In: STACKELBERG A. A. (ed.) Opredelitel much evropejskoj chasti SSSR 7, 742 pp.

ROHDENDORF B. B. 1934. Ueber einige neue Tachinidenarten aus USSR. (Diptera, Larvaevoridae). Doklady Akademii nauk SSSR 1: 151-154.

ROHDENDORF B. B. 1947. A short guide for determining the Dipterous parasites of Eurygaster and other Pentatomid bugs. In: FEDOTOV D. M. (ed.), Vrednaya tsherepashka 2: 75-88.

ROHDENDORF B. B. 1949. A new species of Tachinid of the genus Centeter (Diptera, Larvivoridae) Èntomologicheskoe obozrěnie 30: 418-419.

RUBTZOV I.A. 1951. The morphology and evolution of the abdomen and sexual appendages of phasiid flies (Diptera, Phasiidae). Trudy Vsesoyuznogo Entomologicheskogo Obhschestva 43: 171-249.

SÉGUY E. 1948 a. Diptères nouveaux ou peu connus d'Extréme-Orient. Notes d'entomologie chinoise. Musée Heude. Université l'Aurore 12: 153-172.

SÉGUY E. 1948 b. Trois Diptères nouveaux d'Asie Orientale. Musée Heude. Notes d'entomologie chinoise. Musée Heude. Université l'Aurore 12: 143-147.

SÉGUY E. 1950. Contribution à l'étude de l'Air. Diptères. Mémoires de 1'Institut français d'Afrique Noire 10: 272-282.

SHABLIOVSKiJ V. V.\& LUGovicyNA A. A. 1971 a. Fazii - Parazity chlebnykh klopov v Primorskom krae. Byulleten' Vsesoyuznogo nauchno-issledovatel'skogo instituta zashchity rastenij 18: 49-53.

SHABLIOVSKIJ V.V.\& LUGOVICYNA A.A. 1971 b. Khlebnye klopy v Primorskom krae i rol' entomofagov v ogranichenii ich chislennosti, pp.119-122. In: Kratkie tezisy dokladov $\mathbf{k}$ soveshchaniju po priemam biologicheskoj bor'by s vrednoj tsherepashkoj v integrirovannoj sisteme "Zashchity zernovykh kul'tur", 23-26 noyabrya 1971 g., Voronezh.

ShIMA H. 1980. Study on the tribe Blondeliini from Japan (Diptera: Tachinidae) III. Descriptions of a new genus and two new species from Japan, Korea and Nepal, with notes on Drinomyia bicoloripes (Mesnil). Kontyû 48 : $259-266$

SHIMA H. 1992. Tachinidae (Diptera) collected in Ussuri by Prof. T. Saigusa. Makunagi (Acta Dipterologica) 17:15-20.

SHIMA H. 1999. Host-parasite catalog of Japanese Tachinidae (Diptera). Makunagi (Acta Dipterologica), Suppl. 1: 1-108.

SuN X. 1966. Studies on the genus Lophosia Meigen from China (Diptera: Phasiinae). Acta Zootaxonomica Sinica 21: $95-106$.

Sun X. \& MARshall S. A. 1995. Two new species of Cylindromyia Meigen (Diptera, Tachinidae), with a review of the eastern Palaearetic species of the genus. Studia dipterologica 2: 189-202.

SuN X. \& MARShall S. A. 2003. Systematics of Phasia Latreille (Diptera: Tachinidae). Zootaxa 276. Magnolia Press, $320 \mathrm{pp}$.

TAKANO S. 1956. Systematic and ecological studies of Tachinidae, pp. 59-63. Annual Report of Cooperative Research (Agriculture, 1955). Ministry of Education, Tokyo [In Japanese]

TAKano S. 1958. Phasiidae, pp.1690-1692 + (p.1718). In: EsaKi T., Ishil T., KaWAMURA T., Kinoshita S., Kuwayama S., ShIRAKi T., Uchma S. \& YuASA H. (eds), Iconographia Insectorum Japonicorum. $2^{\text {nd }}$ ed. Improve. Hokuryukan, LTD., Tokyo, 1738 pp.+ index 203 pp. 
TSCHORSNig P.H.\& RICHTER V. A. 1998. 3.54. Family Tachinidae, pp. 691-827. In: PAPP L. \& DARVAS B. (eds), Contributions to a Manual of Palaearctic Diptera (with special references to flies of economic importance). Volume 3. Higher Brachycera. Science Herald, Budapest. $880 \mathrm{pp}$.

UEDA S. 1960 a. Description of a new species of the genus Plesioestrus Villeneuve, with notes on Aulacephala hervei Bequaert (Diptera, Larvaevoridae). Insecta matsumurana 23: 14-20.

UEDA S. 1960 b. A new species of the genus Carcelia from Japan (Diptera, Larvaevoridae). Insecta matsumurana 23 $112-114$.

VIKTOROV G. A. 1960. Faktory dinamiki chislennosti vrednoj cherepashki (Eurygaster integriceps Put.) na Kubani v 1956-1958 gg, pp. 222-236. In: FEDoTov D. M. (ed.), Vrednaya tsherepashka (Eurygaster integriceps Put.). 4. Akademiya Nauk SSSR, Moskva, $240 \mathrm{pp}$.

VIKTOROV G. A. 1966. Dipteran and hymenopteran larvae parasitizing nymphs and adult of the Little Tortoise Bug (Eurygaster integriceps Put.). Zoologichesky zhurnal 45: 220-227.

VIKToRov G. A. \& KozHARINA N. F. 1961. Pishchevye svyazi nekotorykh vidov fazii c vrednaoj tsherepashkoj (Eurygaster integriceps Put.) i drugimi klopami v Krasnodarskom Krae (Diptera, Larvaevoridae). Zoologichesky zhurnal 40: 52-59.

VILLENEUVE J. 1936 a. 52. Dipteren. 16. Muscidae. In: Schwedisch-chinesische wissenschaftliche Expedition nach den nordwestlichen Provinzen Chinas, unter Leitung von Dr. Sven Hedin und Prof. Sü Pimg-chang. Arkiv för zoologi uitgivet av K. Svenska Vetenskaps Akademien 27A (34): 1-13.

VLLENEUVE J. 1936 b. Myodaires supérieurs de Chine. Bulletin du Musée royal d'histoire naturelle de Belgique 12 (42): 1-7. VILLENEUVE J. 1937. Myodaires supérieurs de Chine. Bulletin du Musée royal d'histoire naturelle de Belgique 13 (13): 1-4.

VILLERS C. de. 1789. Caroli Linnaei entomologia 3: 1-657.

WALKER F. 1849. List of the specimens of Dipterous insects of the Britisch Museum. London, 4: 689-1172.

WALKER F. 1850-1856. Diptera. In: SAUNDERS W. W. (ed.), Insecta Saundersiana, London, 1-474.

WALKER F. 1858. Characters of undescribed Diptera in the collection of W. W. Saunders. Transactions of the Entomological Society of London, 4: 190-235.

WALKER F. 1859-1860. Catalogue of the Dipterous insects collected at Makessar in Celebes, by Mr. A. R. Wallace, with descriptions of new species. Journal of the Proceedings of the Linnean Society of London, Zoology 4: 97144 (1859), 145-172(1860).

WALKER F. 1860. Catalogue of the dipterous insects collected in Amboyna by Mr. A.R. Wallace, with descriptions of new species. Journal of the Proceedings of the Linnean Society of London, Zoology, 5: 144-168.

WIEDEMANN C. R. W. 1830. Aussereurpäpsche zweiflügelige Insekten. Hamm, 2: XII+1-684.

WulP F. M. van der. 1881. Diptera. In Midden-Sumatraa, Reizen en Onderzoekingen der Sumatra-Expeditie, etc. Natuurlijke Historije 4 (9 Afdeeling): $1-60$.

WULP F. M. van der. 1893. Eeinige Javaansche Tachininen. Tijdschrift voor entomologie, uitgegeven door de Nederlandsche Entomologische Vereeniging 36: 159-188.

ZIEGLER J. 1994. Die Arten der Gattung Phasia, Untergattung Hyalomyia R.-D., in Mitteleuropa (Diptera, Tachinidae). Studia dipterologica 1 (2): 157-180.

ZiEgleR J. \& ShIMA H. 1996. Tachinid flies of the Ussuri area (Diptera: Tachinidae). Contributions to the knowledge of East Palaearctic insects (5). Beiträge zur Entomologie, Berlin, 46: 379-478.

ZIMIN L. S. 1926. Novyj rod i novyj vid gruppy Phasiinae (Diptera). Russkoe entomologicheskoe obozrenie 21:265-268.

ZIMIN L. S. 1928. Novye rody i vidy mukh iz Hivy (Diptera). Izvestiya Vysshikh kursov prikladnoj zoologii i fitopatologii 4: 21-37.

ZIMIN L. S. 1929 a. Kurze Uebersicht der palaearktischen Arten der Gattung Servillia R.-D. (Diptera), II. Russkoe entomologicheskoe obozrenie 23: 210-224.

ZIMIN L. S. 1929 b. Goniomorphomyia rohdendorfi, gen. et sp. n. (Diptera). Russkoe entomologicheskoe obozrenie 23: 89-92.

ZIMIN L. S. 1931 a. O systematicheskom polozhenii Servillia persica Portsch. i o novykh vidakh rodov Cnephaotachina i Goniomorphomyia. Izvestiya Instituta bor'by s vreditelyami i boleznyami sel'skogo i lesnogo hozjajstva 1: 171-179.

ZIMIN L. S. 1931 b. Palearkticheskie vidy poda Hystromyia Portsch. Ezhegodnik’ Zoologicheskogo muzeya Akademii Nauk SSSR 32: 29-35.

ZIMTN L. S. 1935. Le systéme de la tribu Tachinini (Diptera, Larvaevoridae). Travaux de 1'Institut zoologique de l'Académie des sciences de 1'URSS 2: 509-636.

ZIMIN L. S. 1947. Novye dannye o rode Schineria Rondani (Diptera, Larvaevoridae). Doklady Akademii nauk SSSR 58: $1829-1832$.

ZIMIN L. S. 1949. Novyj vid roda Choremia Zim. (Diptera, Larvaevoridae) iz Srednej Azii. Èntomologicheskoe obozrenie 30: $420-422$.

ZIMIN L. S. 1951. Novyj vid palearkticheskoj mukhi iz roda Fabriciella Bzz. (Gigliomyia Zim.) fauny SSSR, Sbornik rabot Instituta prikladnoj zoologii i fitopatologii 1: 37-40.

ZIMIN L. S. 1954. Vidy roda Limnaemyia R.-D. (Diptera, Larvaevoridae) fauny SSSR. Trudy Zoologicheskogo instituta. Akademya Nauk SSSR 11: 258-282. 
ZIMIN L. S. 1957. Revision de la soustribus Emestiina (Diptera, Larvaevoridae) de la faune paléarctique, I. Èntomologicheskoe obozrenie 36: 501-537.

ZIMIN L. S. 1958. Kratkij obzor vidov podtriby Chrysocosmiina fauny SSSR i sopredel'nykh stran (Diptera, Larvaevoridae). Sbornik rabot Instituta prikladnoj zoologii i fitopatologii 5: 40-66.

ZIMIN L. S. 1960. Brief survey of parasitic Diptera of the subtribe Emestiina in the Palaearctic fauna (Diptera, Larvaevoridae), II. Ėntomologicheskoe obozrenie 39: 725-747.

ZIMIN L. S. 1961. A review of the Palaearctic genera and species of the subtribe Peletieriina (Diptera, Larvaevoridae) Trudy Vsesoyuznogo entomologicheskogo obshchestva 48: 230-334.

ZIMMN L. S. 1963. Paraziticheskie dvukrylye podtriby Linnaemyina Palearcticheskoj oblasti. Trudy Vsesojuznogo instituta zashchity rastenij 17: 186-215.

ZIMTN L. S. 1965. Novye paraziticheskie dvukrylye triby Tachinini (Diptera, Tachinidae) fauny SSSR Èntomologicheskoe obozrenie 44: 946-950.

ZIMIN L. S. 1966. A review of the tribe Gymnosomatini (Diptera, Tachinidae) of the fauna of the USSR, parasitising in the planteating bugs. Èntomologicheskoe obozrenie 45: 423-456.

ZIMIN L. S. 1967. New species of the genus Tachina MG. (Diptera, Tachinidae) parasites of injurious Lepidoptera, from the fauna of the USSR. Èntomologicheskoe obozrenie 46: 468-477.

ZIMIN L. S. 1970. Sem. Tachinidae (Larvaevoridae) - Takhiny (partim), pp. 678-798. In: BEJ-BENKO G. Ya. (ed.), Opredelitel' nasekomykh evropejskoj chasti SSSR, Vol. 2. Nauka, Leningradskoe otdelenie, Leningrad, 944 pp.

ZIMIN L. S. 1974. Novye takhiny (Diptera, Tachinidae) fauny SSSR. Èntomologicheskoe obozrenie 53: 459-469.

ZIMIN L. S. 1980. New species of Tachinids (Diptera, Tachinidae). Èntomologicheskoe obozrenie 59: 206-222.

ZIMIN L. S.\& Kolomyetz N. G. 1983. Paraziticheskie dvukrylye roda Histromyia Portsch. (Diptera, Tachinidae) fauny SSSR. In: Fauna i ekologiya chlenistonogikh Dal'nego Vostoka. Dal'nevostochnyj Nauchnyj Centr Akademii Nauk SSSR 1983: 43-59.

ZIMIN L.S. \& KOLOMYETZ N. G. 1984. Paraziticheskie dvukrylye fauny SSSR (Diptera, Tachinidae). Opredelitel'. Izdatelstvo "Nauka". Sibirskoe Otdelenie. Novosibirsk: 1-233.

\section{STRESZCZENIE}

\section{[Stan wiedzy o faunie rączyc Azji Wschodniej z uwzględnieniem nowych danych z Korei Pólnocnej. Cz. 1. Phasiinae]}

Opracowany materiał muchówek z rodziny Tachinidae został zebrany przez pracowników Instytutu Zoologii PAN w Warszawie w latach 1959-1990 podczas 5 ekspedycji do Korei Północnej. Muchówki były zbierane głównie siatką entomologiczną lub czerpakiem, jedynie w dwu ostatnich wyprawach zastosowano również pułapki Moerick'a. Zgromadzony material Tachinidae liczy niewiele ponad 200 okazów, jest on jednak dość zróżnicowany i interesujący. W obrębie opracowanej podrodziny znaleziono 13 gatunków z 8 rodzajów Phasiinae, z czego zaledwie trzy gatunki byly dotychczas wymieniane z Pólwyspu Koreańskiego. Z omawianej podrodziny wykazano 10 gatunków nowych dla Korei Północnej.

W opracowanym materiale wyodrębniono dwa nowe dla nauki gatunki Phasiinae, są to Dionaea karinae sp. nov. i Hemyda dominikae sp. nov. Oba gatunki znalezione były w górach Mjohjang-san w prowincji Phjŏngan-pukto. Nowy gatunek Dionaea karinae sp. nov. jest morfologicznie najbardziej zbliżony do palearktycznego gatunku Dionea aurifrons (Meig.), od którego różni się bardzo wąską pręgą czołową oraz wąskimi policzkami jak również ilością i ustawieniem szczecin czolowych. Następny nowy gatunek Hemyda dominikae sp. nov. jest morfologicznie najbardziej zbliżony do występującego również na Dalekim Wschodzie gatunku Hemyda obscuripennis (Meig.) od którego różni się szerokością ciemienia i pręgi czołowej, nieznacznie nerkowatymi oczami oraz jednolicie pomarańczowym odwlokiem, jak również odmienną budową zaodwłoka (pokładełka). W pracy podano opisy morfologiczne form dorosłych, omówiono cechy różniące nowe gatunki od najbliższych im gatunków oraz zilustrowano je kolorowymi fotografiami.

W pracy omówiono także stan poznania fauny Tachinidae Dalekiego Wschodu oraz podano obszerny wykaz piśmiennictwa dotyczący ich występowania w tej części kontynentu. 